\title{
Self-Determination Scale: The Adaptation Study
}

\author{
Müge ERSOY KART ${ }^{*} \quad$ Özgür GÜLDÜ ${ }^{* *}$
}

\begin{abstract}
The aim of the present study was to adaptate in Turkish and determine the reliability and validity of the SelfDetermination Scale. The original scale was translated into Turkish and then administered to 232 university students. Factor analysis of the scale yielded a 2-factor solution with 5 items established in the first factor (self-contact) and 4 in the second (choicefulness). The reliability coefficient of the "self-contact" and "choicefulness" subscales were .67 and .71 respectively. This scale has limited crition related validity, with a positive correlation between the Empatic Trend Scale and both scale and sub-scales but with no correlation between otonomy scale and both scale and sub-scales. The two sub-scales can be predict the empathy scores and thereof it can be said that this scale has adequate prediction validity. The finding of the present study were discussed in the light of the literature and the future studies.
\end{abstract}

Key Words: Self-Determination Scale, reliability,validity

\footnotetext{
* Assist. Prof. Dr., Faculty of Political Sciences, Department of Labor Economics And Industrial Relations, Division of Psychology of Administration and Labor, ersoy@politics.ankara.edu.tr

Specialist Psychologist, Ankara University, Milli Piyango Dormitory,guldu@ankara.edu.tr
} 


\section{SUMMARY}

According to the Self-Determination Theory (Deci and Ryan, 1996), there are three "innate psychological needs": Otonomy, competence and relatedness. In the theory, "self-determination" is not seen the same thing as "independence", thereof a person is self-determined when he or she has initiative on their action. Then self-determination is about the degree helded by someone the responsibility of own decide and actions. Self-advocacy can bring to the individuals freedom for control their needs and goals. Only selfcontacted person who also is aware of the choices standing before them, can be self-determined. Social environment will be effective on the selfdeterminated actions, too.

In present study it is aimed to explore the adequacy of SDT for Turkish university students and invastigated the psychometric qualities of the scale. The original scale was translated into Turkish and then administreted to 232 university students. For validity analysis was used Empathy Trend Scale and Otonomy subscale of Sociotropy-Otonomy Scale. For all analysis alpha value was choosen as .05 . Factor analysis of the scale yielded a 2 -factor solution with 5 items established in the first factor (self-contact) and 4 in the second (choicefulness). The reliability coefficients of the "self-contact" and "choicefulness" subscales were .67 and .71 respectively. There were found no corelation between otonomy scale and subscales. But positive correlation were found between Empathy Trend Scale and both scale and subscales. In spite of limited criterion-based validity, the scale can predict the empathy scores, so it can be said the scale has adequate prediction validity and this is consistent with the literatüre. The results of the study were discussed acccording the relevance of the literatüre. 


\title{
Özerk Benlik Yönetimi Ölçeği: Uyarlama Çalışması
}

\author{
Müge ERSOY KART ${ }^{*} \quad$ Özgür GÜLDÜ ${ }^{* *}$
}

ÖZ. Bu çalışmanın amacı “Özerk Benlik Yönetimi Ölçeği”nin Türkçe’ye uyarlanması ile güvenirlik ve geçerliliğinin belirlenmesidir. Özgün ölçek Türkçeye çevrilmiş ve uygulanmıştır. Faktör analizi iki faktörlü bir çözüm ortaya çıkarmıştır. Buna göre beş madde birinci faktöre (bireysel farkındalık), dört madde ikinci faktöre (seçim hakkı) yerleşmiştir. Ölçeğin her iki faktörü için de iç tutarlılık katsayısı. 70'dir. Bireysel farkındalık faktörü ile seçim hakkı faktörü için iki yarı güvenirlik katsayıları sırasıyla. 67 ve. 71 olarak hesaplanmıştır. "Empati Eğilim Ölçeği” ile Özerk Benlik Yönetimi Ölçeği ve iki alt ölçeği arasında pozitif korelasyon hesaplanmış ancak otonomi ile ÖBYÖ ve alt ölçekleri arasındaki korelasyonlar anlamsız çıkmıştır. Buna göre ölçeğin ölçüt bağıntılı geçerliği sınırlıdır ancak iki alt ölçekten elde edilenler puanların empati eğilimini yordadığ bulunmuştur. $\mathrm{Bu}$ durumda ölçeğin yeterli düzeyde yordama geçerliğine sahip olduğu görülmüştür. Araştırma sonuçları, ilgili literatür ışığında ve gelecekteki araştırmalar açısından tartışılmıştır.

Anahtar Sözcükler: Özerk Benlik Yönetimi Ölçeği, güvenirlik, geçerlik

\footnotetext{
* Yrd. Doç. Dr. Ankara Üniversitesi Siyasal Bilgiler Fakültesi Çalışma Ekonomisi ve Endüstri İlişkileri BölümüYönetim ve Çalışma Psikolojisi ABD Öğretim Üyesi, ersoy@politics.ankara edu.tr

${ }^{\star *}$ Uzman Psikolog, Ankara Üniversitesi Milli Piyango Öğrencievi, guldu@ankara.edu.tr
} 


\section{GíRISS}

İnsanoğlunun içinde bulunduğu dünyayı nasıl anlamlandırdığını keşfetmek uzun yıllardır psikoloji biliminin ilgi odağında yer almıştır. Gerçekte hepimiz yaşam boyu sosyal dünyanın etkin bir bireyi olmayı isteriz. Ancak insanlar bazen kendini sinırlamakta ve sorumlulukları üstlenmekte zorluklar yaşayabilirler. Çünkü bunun için gerekli özdüzenleme süreçlerini başarıyla kullanmak zordur. Ryan ve Deci (2000) sosyal bağlamların bu hususta belirleyici olacağını ve insanların kendini güdüleme, bireysel gelişme, etkin olma vb. açılardan farklılaşacağını öngörmektedir.

Özerk Benlik Yönetimi Kuramı'na göre (Self Determination Theory) insanlar gelişmek için doğuştan bir eğilim taşıyan aktif organizmalardır. Ancak bu eğilim kendiliğinden etkinleşmemekte, sosyal çevrenin desteğiyle ortaya çıkmaktadır. O nedenle, insanoğlunun faaliyetleri sosyal bağlam tarafindan bazen kolaylaştırılmakta, bazen de zorlaştırılmaktadır (Deci ve ark., 1994). Buna göre aktif organizma ile sosyal bağlam arasındaki etkileşim, Özerk Benlik Yönetimi Kuramı'nın davranış, deneyim ve gelişim hakkındaki yordamalarına temel oluşturmaktadır (www.psych.rochester.edu/SDT, 25.05.2006). Bilindiği gibi güdülenmeyle ilgili önemli bir kavram "gereksinimdir". 1960'larda bilişsel kuramlara doğru yönelimle beraber bunun yerini "amaçlar" kavramı almıştır. Buna göre odaklanılan şey seçilen ve peşine düşülen amaçların "içeriği" olmak yerine, amaçları seçme ve peşine düşme "süreçleri" haline gelmiştir (Deci ve Ryan, 2000). İşte Özerk Benlik Yönetimi Kuramı, amaçlar ya da sonuçların içeriği ile bunların elde edildiği düzenleyici süreçleri birbirinden ayırmıştır. Chirkov ve arkadaşlarına (2003) göre kuram, her kültürden insanın, bazı doğuştan gelen psikolojik gereksinimleri paylaştığını belirtmektedir. Ayrıca bu temel evrensel psikolojik gereksinimler giderildiğinde birey sağliklı olabilecektir. Kuramda ifade edilen "doğuştan gelen psikolojik gereksinimler" üç başlıkta özetlenebilir: Özerklik (otonomy) gereksinimi, yetkinlik (competence) gereksinimi ve başkalarıyla sosyal ilişki (relatedness) gereksinimi. Özerklik gereksinimi kişinin eylemlerinin kontrol edildiği ya da o eylemlerde bulunmaya zorlandığını hissetmesi yerine eylemlerinde, kendi kendine karar verebildiğini duyumsamasıyla ilgilidir. Yetkinlik gereksinimi ise, kişinin çevresiyle başa çıkabilmek için kendini yeterli hissetme isteğine karş11ık gelir. Başkalarıyla sosyal ilişki gereksinimi de kişinin tatmin edici ve destekleyici sosyal ilişkilere sahip olduğunu hissetme ihtiyacını simgeler (Gagne ve Deci, 2005; Ingledew ve ark., 2004; Kowal ve Fortier, 1999). Guay ve ark. (2003) iyilik-hali duygusunun yaşanabilmesi ve psikolojik 
gelişme için bu üç temel gereksinimin karşılanmasının zorunluluğuna işaret etmişlerdir.

Ancak özerklik gereksiniminin evrenselliği hakkında bazı tereddütler söz konusudur. Örneğin Chirkov ve ark. (2003), özerkliğin temel bir gereksinim oluşunun pek çok kez inkâr edildiğini belirtmiş̧lerdir. Iyengar ve Lepper (1999) de özerklik arayışının ait olma ve gruba bağlılık gibi kültürel değerlerle çeliştiğini dile getirmişlerdir. Bu yaklaşımda kuramın, "özerklik" ile "referans grubundan bağımsız tercih yapabilme" kavramını anlamdaş gibi ele aldığı düşünülebilir. Her ne kadar "özerklik" ve "bağımsızlık" aynı şeymiş gibi görünse de bu iki terim kuramda son derece farklı anlamlarda kullanılmaktadır. Kurama göre, bir kişi eylemini "isteyerek" gerçekleştiriyor ve bu eylemleri "tamamen onayliyor" ise özerk kabul edilir (Ryan ve Deci, 2000). Dolayısıyla birey davranışı üzerinde inisiyatif sahibi olduğunu hissetmekte ve yaptıklarının savunucusu olmaktadır. Zaten Özerk Benlik Yönetimi Kuramı'na göre, otonominin karşı ucu bağımlılık olmak yerine heteronomidir; yani bireyin eylemleri "yabancı" güçlerce kontrol edilmekte ya da kişi kendi değerlerine uygun olmayan biçimde davranmak zorunda bırakılmaktadır (Chirkov ve ark., 2003). Ryan ve Lynch'a (1989) göre Özerk Benlik Yönetimi Kuramı, bağımlılığı, başkalarının yol göstericiliğine ve desteğine gereksinme olarak tanımlamaktadır. O halde, bağımlılığın karşıtı özerklik değildir. Aksine başkalarının desteğine ihtiyaç duymama ve başkalarından medet ummama anlamına gelen "bağımsızlık" karşı ucu temsil edecektir (Chirkov ve ark., 2003). Özetle, kurama göre özerklik bir kişinin eylemlerini ne derece kabul ettiği ve yaptıklarının sorumluluğunun ne kadarını taşıdığıyla ilgilidir (Ryan ve Deci, 2000).

Görüldüğü gibi kuram, özerklik gereksinimini evrensel olarak tanımlıyorsa da, bağımsızlığı (indepence) ve bireyciliği (individualism) kültüre özgü değerler olarak betimlemektedir (O’Brien, 2006). Bazen bireyler başkalarına bağımlı olmayı kendileri özgürce seçebilirler. Aynı şekilde birey bağımsız görünmesine karşın kararlarında özerk olmayabilir. Örneğin ailesi üniversite eğitimi almasını çok önemli bulan ve bu beklentiyi karşılama baskısı duyumsayan bir genç, sanki bu kendi kararıymış gibi davranabilir (Villacorte, 2006). Kuşkusuz böyle bir kararın özerkliğinden söz edilemez. Otonomi, bireycilikle de anlamdaş değildir. Dolayısıyla birey hem özerk karar verebilir hem de toplulukçu (collectivist) olabilir; buna karş1lık bireyci eğilimlere sahip olsa da özerk karar verememesi de mümkündür.

İnsanlar günlük yaşamlarında farklı etkenler sonucunda, farklı eylemlerde bulunmak üzere güdülenebilirler. Çıkarları nedeniyle öyle davranıyor olabilecekleri gibi, baskılara direnemedikleri ve zorda 
bırakıldıkları için de herhangi bir eylemde bulunabilirler. Dolayısıyla "içten güdülenme" ile "dıştan zorlanma" arasındaki tezat hepimiz için çoğu koşulda tanıdıktır (Ryan ve Deci, 2000). İşte, Özerk Benlik Yönetimi Kuramı güdülenmeyi kendi içinde sınıflandıran bir yaklaşımı benimsemekte ve belli bir anda hangi türdeki güdülenmenin sergileneceğini sorgulamaktadır. $\mathrm{Bu}$ amaçla kuram, içsel (intrinsic) ve dışsal (extrinsic) güdülenme arasında bir ayrım öngörmektedir. İçsel güdülenmede bireyin söz konusu eyleme yönelmesinin nedeni eylemin bizzat kendisinden elde edeceği haz ve tatmindir. Dışsal güdülenme söz konusu olduğundaysa, birey dışsal ödül ya da kendisi için önemli sonuçları elde edebilmek üzere bir davranışta bulunur (Ingledew ve ark., 2004).

Kuram, içsel ve dışsal güdülenme ayrıştırmasının yanı sıra, bireyin dayatılan eylemi yapmak üzere "dışsal" güdülenişini de farklılaştırmaktadır. Buna göre, bireyin davranışlarını düzenleyebileceği çeşitli yollar vardır ve bu seçenekler "özerk karar verme sürekli çizgisi" üzerinde oluşmaktadır (Ingledew ve ark., 2004). Özerk Benlik Yönetimi Kuramı, bireyin dışsal bazı zorlamaları "içsel düzenlemeler" haline dönüştürerek, "içselleştirdiğini”" ileri sürmektedir. Bu süreç olması gerektiği gibi işlerse, birey dışsal zorlamaları benliğinin bir parçasıymış gibi tanımlayarak, o eylemde bulunmak üzere güdülenebilir (Deci ve ark., 1994).

Kuram, söz konusu içselleştirme sürecinin içe yansıtma (introjection), özdeşleşme (identification) ve bütünleştirme (integration) mekanizmalarıyla gerçekleştirilebileceğini ileri sürmektedir (Ingledew ve ark., 2004). İçe yansıtma aracılığıyla birey dışsal dayatmaları, suçluluktan kaçmak ve mevcut özsaygısını korumak için benliğiyle uyumlu hale getirmeye çalışmaktadır; bu nedenle davranışı, sadece kısmen özerk bir karara dayanmaktadır. Özdeşleşme aracılığıyla düzenlendiğinde ise davranış, daha güçlü bir özerk karar verme sürecinin sonucudur; çünkü birey kişisel olarak değer verdiği sonuçlara erişmek amaciyla sözkonusu davranışı gerçekleştirmektedir ve davranış kendi benlik duygusuyla tamamen örtüşmektedir. Bütünleştirilmiş düzenlemede ise hiçbir baskı duygusu olmaksızın birey o davranışı sergilediğinden, tamamen özerk karar verilmiş bir eylem ortaya çıkmaktadır (Deci ve ark., 1994; Ingledew ve ark.,2004).

Daha önce değinildiği gibi kuram içsel ve dişsal güdülenme süreçlerinin, sürekli bir çizgi üzerinde konumlandırılabileceğini ileri sürmektedir (Gagne ve Deci, 2005; Kowal ve Fortier, 1999). En yüksek özerk karar verilmiş güdülenmeden, en düşük özerk karar verilmiş güdülenmeye doğru uzanan bu çizgi üzerinde dört ayrı güdülenme süreci tanımlanmıştır. Bunlar, içsel güdülenme, özerk karar verilmiş dışsal güdülenme, özerk karar verilmemiş dışsal güdülenme ve güdülenmeme 
(amotivation) durumudur. İçsel güdülenme bireyin kendi çıkarları doğrultusunda haz ya da doyum elde etmek üzere o davranışta bulunmasını ifade ederken, dışsal güdülenme ödüllere erişmek ya da cezadan kaçmak için yönelinen davranışları ortaya çıkarır. Deci ve Ryan (1985) dışsal güdülenmeyi de kendi içinde iki tipe ayırmışlardır: Özerk karar verilmiş dışsal güdülenme ile özerk karar verilmemiş dışsal güdülenme (Akt., Kowal ve Fortier, 1999). Özerk karar verilmiş dişsal güdülenme, kişinin kendi bağımsız tercihiyle bir eylemde bulunmasına işaret etmektedir. Kişi bu eylemde bulunur çünkü buna değer verir ve önemli olarak algılar. Özerk karar verilmemiş dışsal güdülenme ise bireyin davranışlarının dışsal faktörlerce kontrol edildiğini algılaması ve isteneni yapmazsa suçluluk duyacağı inanciyla, o eylemde bulunması durumudur. Güdülenmeme ise ne içsel ne de dışsal güdülenmenin bulunmaması halini temsil eder. Eylemleri üzerinde hiçbir kontrolleri olmadığını hisseden kişiler bu güdülenme türüne örnektir ve belki de bu durum "öğrenilmiş çaresizlik" davranışına benzetilebilir. $\mathrm{O}$ halde kuram özerk karar verilmiş güdülenmenin iki türünü (içsel güdülenme ve özerk karar verilmiş dışsal güdülenme) ve özerk karar verilmemiş güdülenmenin de iki türünü (özerk karar verilmemiş dişsal güdülenme ve motivasyon yokluğu) tanımlamış olmaktadır (Akt., Kowal ve Fortier, 1999) .

Kuramda, bireyin kendi hedeflerini tanımlama ve bu hedeflere erişmek için inisiyatifi üstlenme becerisi özerk karar verme olarak tanımlanmaktadır. $\mathrm{Bu}$ da bireyin kendi varlığını göstermesi, başkalarını kendi gereksinimlerinden haberdar etmesi yani gerektiğinde kendini savunmasi (self-advocacy) aracılığıyla mümkündür. Kendini savunmak bireyin haklarını ve bunları nasıl elde edebileceğini bilmesine izin verir. İşte özerk karar verebilenler ne istediklerini ve buna nasıl ulaşabileceklerini bilmekle yaşamları üzerinde kontrol ve sorumluluk taşırlar. Aslında kendini savunmak bir bakıma "özgürleşmektir" (http://www.state.sd.us/deca/24.11.2006).

Kendini savunabilmek için birey gereksinimlerini, çıkarlarını, bunları karşılamak için mevcut gücünü ve sınırlılıklarını bilmeli yani "bireysel farkındalığa" (self-contact) erişebilmelidir. Ayrıca karar verme aşamasında durumun gereklerini kavramak, mevcut seçenekler arasından en iyisini tercih etmek için birey "seçme hakkı" (choicefulness) olduğunu da hissetmelidir. Dolayısıyla çevresel koşullar özerk karar verme üzerinde etkilidir. Shaldon ve Deci (1996) de geliştirdikleri ölçekte özerk karar vermenin bu önemli iki boyutunu belirlemeyi hedeflemişlerdir. Dolayısıyla "kendi isteklerinin farkında olmak" ve davranışlarında "seçme hakkı" olduğunu hissetmek özerk karar vermeyi biçimlendirmektedir. 
Karar verme sürecinin daima duygusal bir boyutu vardır. Bireyin kendi kararlarının başkalarını nasıl etkilediğini düşünmesi empatik eğilimleri gerektirir. Empati başkalarını anlamamızı ve onlar hakkında kimi tahminlerde bulunmamızı sağlarken, başkalarınca sevilmek için bir araç da olabilir. Başkalarıyla sosyal ilişki (relatedness) gereksinimi bireyin başkalarını önemsemesini ve vereceği karar ile diğer kişilerin istek ve gereksinimleri arasındaki bağlantıyı göz önünde tutmasını sağlar. Bu durum grup normlarının içselleştirilmesi, benlik duygusunun derinleşmesi ve empati kapasitesinin yoğunlaşması aracılığıyla güçlü sosyal temaslara yol açar (Malhotra, 2004). Dolayısıyla kendini başkalarının yerine koymak "gönüllü̈", yani içten güdülenmiş bir davranış kararına zemin hazırlar. Bu durumda empatik eğilimler başkalarının dayattığı bir eylemi bireyin gözünde makulleştirebilir. Böylece empati "ahlaki çelişkileri” bireyin görmesine izin verir. $\mathrm{Bu}$ bağlamda başkalarıyla sosyal ilişki gereksinimi de empatik eğilimlerle bağlantılıdır. O nedenle, kendini başkalarıyla bütünleştirme de özerk karar vermeyi etkileyebilecektir (Shogren, 2006). Dolayısıyla özerk karar verme ile empati arasında doğru yönlü bir ilişki beklenmektedir. Ayrıca Deci ve Ryan (2000), özerk karar verme düzeyinin empatik eğilimleri yordadığını bulmuşlardır ve kendini başkalarının yerine koyabilmenin içten güdülenmiş özerk karar vermeyi teşvik edeceğini düşünmüşlerdir.

Okul, işyeri, aile gibi hemen hemen her sosyal ortam insanlara belli bazı davranış ve değerlerin uygun olduğunu ima edici özelliklere sahiptir. Bu örtük biçimde önerilen değer, tutum ya da davranışları bireyin benimsemesi ve içselleştirmesi, güdülenme mekanizmaları aracılığıyla gerçekleşmektedir. Sosyal çevre, temel sosyal gereksinimleri karşlayarak bireyi desteklediğinde psikolojik gelişme gerçekleşecektir. Kontrol edici bir çevre özerk davranışları ketleyebilir. O nedenle bireyin, dışarıda davranışı kontrol eden faktörlere karş1 güçlenmesi gereği söz konusudur (Shogren, 2006). Kurama göre insanlar ilginç buldukları eylemleri sergilemek için doğuştan gelen bir gereksinime sahipse de bazen, içselleştirmeden de önerilen ve hatta dayatılan eylemleri yapabilmektedirler. O halde sosyal çevre özerk karar verme süreci üzerinde belirleyicidir. $\mathrm{Bu}$ husus, özellikle klinik tedavi alan hastalar açısından önemlidir. Terapilerin kısıtlı verimliliği ya da tamamen başarısız kalışı, hastanın telkin ve / veya ilaç uygulamalarını "kendi kararı olarak" benimsemesiyle ve tıbbi önerileri izlemek üzere güdülenmesiyle aşılabilecektir. Aynı şekilde eğitim sürecine isteyerek katılan gençlerin çok daha yetkin olması beklenebilir. O nedenle, hasta-hekim-çevre ile okulöğrenci-veli işbirliğini sağlamak için, özerk karar verme düzeylerinin belirlenmesi ciddi katkılar sağlayabilir. Bu çalışmada Sheldon ve Deci'nin 
(1996) geliştirmiş olduğu Özerk Benlik Yönetimi Ölçeği'nin Türk Kültürüne uyarlanması ile geçerlik ve güvenirliğinin belirlenmesi amaçlanmıştır.

\section{YÖNTEM}

\section{Araştırma Grubu}

Bu araştırmanın örneklemi, Ankara Üniversitesinin çeşitli fakültelerinde öğrenim gören ve seçkisiz olarak atanan 232 üniversite öğrencisinden oluşmuştur. Katılımcıların 126'sı (\%54) kız ve 106'sı (\%46) erkektir. Kız öğrencilerin yaş ortalaması $21.91(\mathrm{~S}=1.85)$ iken, erkek öğrencilerin yaş ortalamas1 $22.11(\mathrm{~S}=1.48)$ dir.

Veri Toplama Araçları

\section{Özerk Benlik Yönetimi Ölçeği (Self-Determination Scale)}

Özerk Benlik Yönetimi Ölçeği, Sheldon ve Deci (1996) tarafindan özerk karar vermedeki bireysel farklılıkları değerlendirmek amacıyla geliştirilmiştir. 10 maddeden oluşan özgün ölçek, "bireysel farkındalık" (self-contact) ve "seçim hakkı" (choicefulness) olmak üzere iki faktöre sahiptir. Katılımcılardan ölçekte verilen ifade çiftlerinden onlara göre en doğru görüneni belirlemeleri istenmektedir. Örneğin "Duygularım bazen bana yabancı gibi görünür" ifadesine karşı, "Duygularımın daima bana ait olduğunu düşünürüm" ifadesi "bireysel farkındalık" koşulunu simgeler; "Yaptığım şey çoğunlukla yapmayı seçtiğim şey değildir" ifadesine karşı "Karar verdiğim her şeyi yapmakta özgürüm" ifadesi "seçim hakk1" koşuluna işaret etmektedir. Katılımcılar bu belirlemeyi "sadece A ifadesi tamamen doğru" dan "sadece B ifadesi tamamen doğruya" uzanan likert tipi dokuz basamaklı ölçeğe göre yapmaktadırlar. Puanlama sonrası hem toplam özerk karar verme puanı elde edilebilmekte, hem de iki alt boyuta ait puanlara ulaşılabilmektedir. Özgün ölçeğin uygulandığı birçok örneklemde, alfa değerlerinin .85 - .93 arasında bir dağılım göstermesi, ölçeğin iyi bir iç güvenirliğe sahip olduğuna işaret etmektedir. Test-tekrar test güvenirliği, 8 haftalık arayla uygulandığında .77 olarak bulunmuştur. Bu ölçek ile kendini gerçekleştirme, empati ve yaşam doyumunu içine alan psikolojik sağlik ölçütleri arasında ve yaratıcılık, akran baskısına direnme ve otonomi arasında da güçlü bir ilişki bulunmuştur (Sheldon ve ark., 1996). Ancak uyarlama çalışması öncesi yapılan deneme uygulamasında dokuz basamaklı yanıt formunun, Türkçe için pek uygun olmadığı, katılımcıların yargılarını derecelendirme orta nokta tespitinde zorlandıkları ve çoğunun ölçeği yanıtsız bıraktıkları görülmüştür. Türkçe uygulamalar için beş basamaklı likert tipinin ideal olduğuna dair yaygın eğilim de (http://www.bayar.edu.tr/ saykad/o_aydemir1.pdf) göz önüne alınarak ölçeğin puanlaması buna uygun hale getirilmiştir. 


\section{Empatik Ĕgilim Ölçeğ $i-E E O ̈$}

Dökmen (1988) tarafindan geliştirilmiş olan bu ölçeğin amacı, kişilerin empatik duyarlılığını ve günlük yaşamdaki empati kurma potansiyellerini ölçmektir. 20 maddeden oluşan ve likert tipi bir ölçek olan EEÖ'nün maddelerinin yaklaşık yarısı, deneklerin "evet" deme eğilimlerini dengeleyecek şekilde yazılmıştır. Güvenirlik çalışmasında ölçek 70 kişilik bir öğrenci grubuna üç hafta ara ile iki defa uygulanmış ve iki uygulama arasında .82 düzeyinde anlamlı ilişki bulunmuştur. Deneklerin, ölçeğin tek ve çift maddelerinden aldıkları puanlar arasındaki ilişki ise .86'dır. Testin geçerlilik çalışmasında ise 24 kişilik bir gruba EEÖ ile Edwards Kişisel Tercih Envanterinin "Duyguları Anlama" alt ölçeği birlikte uygulanmış ve aralarında .68 düzeyinde bir ilişki bulunmuştur (Dökmen, 1988).

\section{Otonomi Ölçeği}

Şahin ve arkadaşları (1993) tarafindan Türkçe'ye uyarlama çalışması yapılan Beck, Epstein, Harrison ve Emery'nin 1983'te geliştirdiği Sosyotropi-Otonomi Ölçeği'nin başarıya, bağımsızlığa ve özgürlüğe önem veren otonomik kişilik özelliğini ölçmek üzere hazırlanan "Otonomi alt ölçeği” araştırmada kullanılmıştır. Ölçek 30 maddeden oluşmakta olup, her madde "sizi ne kadar tanımlıyor?" sorusuna karşılık "hiç tanımlamıyor"dan başlayıp, "çok iyi tanımlıyor"a kadar giden seçeneklerle cevaplandırılmaktadır. Otonomi alt ölçeğinden alınan yüksek puanlar kişinin yüksek düzeyde otonom özelliklere sahip olduğunu göstermektedir. Ölçeğin depresyon hasta grubu üzerinden elde edilen Cronbach alfa katsayıs1 .81, ögrenci grubundan elde edilen Cronbach alfa katsayısı ise yine .81 olarak bulunmuştur (Savaşır ve Şahin, 1997). Şahin ve arkadaşları (1993) tarafindan yapılan geçerlik çalışmasında Fonksiyonel Olmayan Tutumlar Ölçeği (FOTÖ) ve Beck Depresyon Envanteri'yle Otonomi Ölçeği arasında anlamlı bir ilişki bulunamamıştır.

Bu çalışma, daha önce de belirtildiği gibi, Sheldon ve Deci'nin (1996) geliştirdikleri Özerk Benlik Yönetimi Ölçeği'ni Türkçe’ye uyarlayarak ölçeğin geçerlik ve güvenirlik kanıtlarını saptamak amacıyla yapılmıştır. Özerk Benlik Yönetimi Ölçeği iki sosyal psikolog ve dil uzmanı tarafından Türkçe'ye çevrilmiştir. Ardından uzmanların çevirdiği maddeler karşılaştırılarak ortak olan ve olmayan maddeler belirlenmiştir. Daha sonra önerilen bütün maddeler bir araya getirilerek, iki sosyal psikoloji öğretim elemanına çeviri maddeleri tekrar verilmiş ve bu maddeleri değerlendirmeleri istenmiştir. Bu iki öğretim elemanının önerileri de dikkate alınarak ölçeğin Türkçe formu oluşturulmuştur. Son olarak, ölçeğin tekrar 
İngilizceye çevrilmesi ve kontrol edilmesi gerçekleştirilmiş ve bu değerlendirmeler sonucunda son şekli verilmiştir.

\section{Iş̧lem}

Araştırma grubunu oluşturan öğrenciler anket formunu Ankara Üniversitesi'nin çeşitli bölümlerinde sınıf ortamında, cevaplandırmışlardır. Ölçek gönüllü olan öğrencilere uygulanmıştır. Katılımcılara yaş ve cinsiyet dışında kimlik bilgileri sorulmamıştır.

\section{BULGULAR}

Bu bölümde, Sheldon ve Deci'nin Özerk Benlik Yönetimi Ölçeği'ni uyarlamak üzere üniversite öğrencileri üzerinde yapılan geçerlik ve güvenirlik analizlerine ilişkin bulgulara yer verilmiştir.

Bütün analizler için alfa değeri .05 olarak seçilmiştir. Faktör analizi ile geçerlik -güvenirlik analizleri SPSS 13.0 ile gerçekleştirilmiştir.

\section{Kapsam Geçerliği}

Kapsam geçerliği, testi oluşturan maddelerin ölçülmek istenen özelliği ölçmede nicelik ve nitelik olarak yeterli olup olmadığının göstergesidir (Büyüköztürk, 2004). Bunu sınayabilmek için hazırlanan 10 maddelik deneme formu Psikoloji Bilim Dalı ögrretim üyesi olan üç uzmana inceletilmiş ve soruların geçerliğine ilişkin görüşlerini "geçerli ve geçerli değil" şeklinde belirtmeleri istenmiştir. Uzmanların görüşleri maddelerin geçerli olduğuna işaret etmiştir.

\section{Yapı Geçerliği}

\section{a. Faktör Analizi}

Bir ölçme aracının geçerliği, aracın ölçmeyi amaçladığı özelliği ne denli doğru ölçtüğüne işaret etmektedir. Bilindiği gibi faktör analizinin yapılabilmesi için yeterli sayıda örnekleme ulaşılması gerekmektedir. Örneklemin yeterliğini değerlendirmek üzere hesaplanan Kaiser-MeyerOlkin (KMO) katsayısının (.72) istenir düzeyde çıkması ve faktör analizinin geçerliğini sınayan Bartlett testi sonucunun da anlamlı $(423,017, \mathrm{p}<.000)$ olması nedeniyle faktör analizinin yapılabileceği görülmüştür (Büyüköztürk, 2004).

10 Maddelik “Özerk Benlik Yönetimi Ölçeği”nin yapı geçerliğinin incelenmesi için yapılan açımlayıcı faktör analizi işleminde faktörleştirme tekniği olarak ağırlıklandırılmamış en az kareler (unweighted least squares) yöntemi kullanılmıştır. 
Ölçeğin kaç faktör içerdiği belirlenirken özdeğeri 1 ve 1'den büyük faktörler ele alınmış ve faktörlere ilişkin çizgi grafiğine de bakılmıştır. Gözlenen ve tahmin edilen korelasyon matrisleri arasındaki farkın toplam karesini en aza indirmek amacıyla yapılan "ağırlıklandırılmamış en az kareler analizi" sonucunda maddelerin ortak varyansı açıklama oranlarının 0.26 ile 0.74 arasında değiştiği görülmektedir. Açıklanan toplam varyansa bakıldığında, özdeğeri 1'den büyük olan 3 faktör ortaya çıkmaktadır ve bu üç faktörün ölçeğe ilişkin açıkladıkları varyans \% 41.05'tir. Ancak birinci faktör \%13.75, ikinci faktör \%21.12 varyans açıklarken üçüncü faktörün \% 6.19'luk bir varyans açıklaması, ölçeğin 2 faktörlü olarak kullanılabileceğini düşündürmektedir.

Bileşenler Matrisi (Component Matrix) incelendiğinde de birbirine yakın yük değerleri olduğu belirlenmiş; elde edilen faktörlerin, "bağımsızlık, yorumlamada açıklık ve anlamlılık" açısından belirginleşmesi için, eksen döndürmesine tabi tutulması uygun görülmüş, bu amaçla "promax" tekniği kullanılmıştır.

Döndürme sonrası Bileşenler Matrisi incelendiğinde, üçüncü maddenin ilk iki faktöre yerleşmediği ve üçüncü faktörde tek başına göründüğü tespit edilmiştir. $\mathrm{Bu}$ durumda 3. maddenin ölçeğin faktör yapısı dişında kalan başka bir yapıyı ölçüyor olması endişesi ve tek maddelik bir faktör üzerinden güvenirlik hesaplarının yapılamayacağı nedenleriyle ölçekten 3.maddenin çıkarılarak işlemlerin yenilenmesi uygun görülmüştür. Böylece ölçek iki faktörlü hale dönüşmüştür. Dokuz maddelik ölçeğin döndürülmüş "ağırlıklandırılmamış en az kareler analizi" sonuçları Tablo 1'de sunulmuştur.

Özgün halinden 3. maddenin atılmasıyla iki faktörlü hale gelen Özerk Benlik Yönetimi Ölçeği'nde, birinci faktörde 2, 4, 6, 8 ve 10'uncu maddelerin yer aldığ 1 ; ikinci faktörde 1, 5, 7 ve 9'ncu maddelerin bulunduğu gözlenmiştir. Madde içerikleri incelendiğinde, birinci faktör için en uygun faktör adının "bireysel farkındalık"; ikinci faktör için ise "seçim hakkı" olduğuna karar verilmiştir. $\mathrm{Bu}$ durum orijinal ölçeğin faktör yapısıyla tutarlıdır. 
Tablo 1: Dokuz Maddelik Ölçeğin Son Formunun Promax Döndürme Yöntemine göre Analiz Sonuçlar

\begin{tabular}{|c|c|c|c|}
\hline \multirow[t]{2}{*}{$\begin{array}{l}\text { Madde } \\
\text { No }\end{array}$} & \multirow[t]{2}{*}{ Maddeler } & \multicolumn{2}{|c|}{$\begin{array}{l}\text { Döndürme Sonrası } \\
\text { Yük Değerleri }\end{array}$} \\
\hline & & $\begin{array}{c}\text { Bireysel } \\
\text { Farkındalı } \\
\underline{\mathrm{k}}\end{array}$ & $\begin{array}{l}\text { Seçim } \\
\underline{\text { Hakkı }}\end{array}$ \\
\hline 2 & $\begin{array}{l}\text { A. Duygularım bazen bana yabancı gibi görünür. } \\
\text { B. Duygularımın daima bana ait olduğunu düşünürüm. }\end{array}$ & .51 & -.04 \\
\hline 4 & $\begin{array}{l}\text { A. Kendimi nadiren "kendim" gibi hissederim. } \\
\text { B. Her zaman kendimi "kendim" gibi hissederim. }\end{array}$ & .52 & .04 \\
\hline 6 & $\begin{array}{l}\text { A. Bir şeyi başardığımda, çoğu zaman sanki bunu yapan ben } \\
\text { değilmişim gibi hissederim. } \\
\text { B. Bir şeyi başardığımda, daima bunu yapanın ben olduğuma } \\
\text { inanırım. }\end{array}$ & .47 & -.04 \\
\hline 8 & $\begin{array}{l}\text { A. Bedenim bazen bana yabancıymış gibi geliyor. } \\
\text { B. Daima bu beden benim diye düşünürüm. }\end{array}$ & .69 & .02 \\
\hline 10 & $\begin{array}{l}\text { A. Bazen aynaya bakıyorum ve bir yabancı görüyorum. } \\
\text { B. Aynaya baktığımda kendimi görürüm. }\end{array}$ & .66 & .01 \\
\hline 1 & $\begin{array}{l}\text { A. Yaptığım şeyler her zaman kendi seçimimdir. } \\
\text { B. Bazen yaptığım şeylerin gerçekte kendi seçimim olmadığını } \\
\text { düşünürüm. }\end{array}$ & .01 & .48 \\
\hline 5 & $\begin{array}{l}\text { A. Her ne yapıyorsam sebebi benim ilgimi çekmesidir. } \\
\text { B. Her ne yapıyorsam sebebi bunu yapmaya mecbur olmamdır. }\end{array}$ & -.01 & .57 \\
\hline 7 & $\begin{array}{l}\text { A. Karar verdiğim her şeyi yapmakta özgürüm. } \\
\text { B. Yaptığım şey çoğunlukla yapmayı seçtiğim şey değildir. }\end{array}$ & .01 & .68 \\
\hline \multirow[t]{4}{*}{9} & $\begin{array}{l}\text { A. Tercihlerimde kendimi oldukça özgür hissederim. } \\
\text { B. Çoğu kez kendi seçimim olmayan şeyleri yapıyorum. }\end{array}$ & -.02 & .70 \\
\hline & Özdeğerler & 1.80 & 2.63 \\
\hline & Varyans Yüzdeleri & $\% 13.14$ & $\% 22.33$ \\
\hline & Cronbach Alfa Katsayıları & .70 & .70 \\
\hline
\end{tabular}




\section{$\underline{\text { b. Madde Analizine İlișkin Bulgular }}$}

Madde analizi için madde-toplam puan korelasyonlarından yararlanılmıştır. Madde- toplam korelasyonlarının "bireysel farkındalık" alt ölçeği için .63 ile .74 ve "seçim hakkı" alt ölçeği için ise .64 ile .78 arasında değiştiği belirlenmiştir. Buna göre her bir faktördeki maddeler, o faktörün tümüyle tutarlıdır ve her ilgili madde faktörün ölçtüğü yapıyı ölçmektedir.

Maddelerin ayırt edicilik gücünü yani ölçeğin iç geçerliğini belirlemek üzere "uç grup" (extreme group) yöntemi kullanılmıştır (Tezbaşaran 1997). Üst grup her boyuttan en yüksek puan alan katılımcıların \%27'si $(n=62)$, alt grup ise her bir boyuttan en düşük puan alan katılımcıların \%27'si (n=62) olarak belirlenmiştir. Özerk Benlik Yönetimi Ölçeği'nin boyutlarından alınan puanların uç gruplara ayrılan grupları ne düzeyde ayırabildiğini anlamak amacıyla t-testi analizi yapılmış ve bu analizin sonuçları Tablo 2 'de özetlenmiştir.

Tablo 2: Ölçeğin Genel Olarak Geçerlik Analiz Sonuç Tablosu

\begin{tabular}{ccccc}
\hline & & & & \\
Madde & Düzeltilmiş & Üst & Alt & $\mathrm{t}$ \\
Numaras1 & Madde Top. & 0,27 & 0,27 & Değeri \\
& Kor. & Ortalamas1 & Ortalamas1 & \\
\hline
\end{tabular}

$\underline{\text { Bireysel Farkındalık için Alfa }=0.70}$

\begin{tabular}{lcccc}
2 & .41 & 4.40 & 2.18 & $-12.39^{*}$ \\
4 & .44 & 4.75 & 2.68 & $-11.83^{*}$ \\
6 & .38 & 4.79 & 2.73 & $-10.31^{*}$ \\
8 & .55 & 4.84 & 2.53 & $-13.26^{*}$ \\
10 & .52 & 4.94 & 2.65 & $-14.66^{*}$ \\
& & \multicolumn{2}{l}{ Seçim Hakk1 Faktörü için Alfa=0.70 } & \\
1 & .40 & 3.81 & 2.35 & $-9.03^{*}$ \\
5 & .46 & 4.56 & 2.66 & $-12.60^{*}$ \\
7 & .53 & 4.78 & 2.28 & $-17.39^{*}$ \\
9 & .55 & 4.68 & 2.31 & $-16.43^{*}$ \\
\hline${ }^{*} \mathrm{p}<.05$ & & & &
\end{tabular}

$\mathrm{Bu}$ testin sonuçlarına göre alt ölçeklerin madde ortalamaları arasında anlamlı farklar görülmüştür. Bu durumda maddelerin özerk karar verme eğilimini belirleyen bireysel farkındalık ve seçim hakkı bakımından ayırt edici olduğu kararına varılmıştır. Bilindiği gibi \%27'lik gruplar arasında istendik yönde gözlenen farkların anlamlı çıkması, testin iç tutarlılığının bir göstergesi olarak kabul edilmektedir (Büyüköztürk, 2004). 
Özerk Benlik Yönetimi Ölçeği'nin boyutları arasında hesaplanan .26 korelasyon değeri de ölçeğin geçerliğini destekler nitelikte bulunmuştur.

\section{Ölçüt Bağıntılı Geçerlik}

Özerk Benlik Yönetimi Ölçeği'nin ölçüt-bağıntılı geçerliğini belirlemek üzere, katılımcılardan Empatik Eğilim Ölçeği (Dökmen, 1988) ve Sosyotropi-Otonomi Ölçeğinin (Şahin ve ark.; 1993) Otonomi alt ölçeğini yanıtlamaları istenmiştir. Bilindiği gibi Özerk Benlik Yönetimi Ölçeği, "bireysel farkındalık" ve "seçim hakkı" alt ölçeklerinden oluşmaktadır. Empati ve otonomi puanları ile Özerk Benlik Yönetimi Ölçeği ve bu iki alt ölçekten alınan puanlar arasında hesaplanan korelasyon katsayıları Tablo 3'de özetlenmiştir.

Tablo 3: Ölçüt Bă̆ıntılı Geçerlik Analizi Sonuçları

\begin{tabular}{lccc} 
& $\begin{array}{c}\text { Özerk Benlik Yönetimi } \\
\text { Ölçeği }\end{array}$ & Bireysel Farkındalık & Seçim Hakk1 \\
\hline $\begin{array}{l}\text { Empatik Eğilim } \\
\text { Ölçeği }\end{array}$ & $.39^{*}$ & $.27^{*}$ & $.35 *$ \\
\hline Otonomi Ölçeği & .06 & .07 & .02 \\
\hline$* \mathrm{p}<.05$ & & &
\end{tabular}

Tablo 3'den de izlenebileceği gibi; hem Özerk Benlik Yönetimi Ölçeği hem de "bireysel farkındalık" ve "seçim hakkı" alt boyutları ile empatik eğilim puanları arasında anlamlı korelasyonlar (sırasıly $.39, .27$ ve .35) söz konusudur. Buna göre, Özerk Benlik Yönetimi Ölçeği'nin ve her iki alt boyutu empatik eğilimlerle ilişkilidir. Uygulanan regresyon analizi de ölçeğin iki alt boyutundan elde edilen puanların empati düzeyini yordadığına; seçim hakkı ve bireysel farkındalık puanlarının toplam varyansa anlamlı katkılar yaptığına işaret etmiştir. Buna göre empati için regresyon denklemi aşağıdaki gibi yazılabilmektedir:

$$
\text { Empati }=48.04+0.95(\text { Seçim Hakkı) }+0.47 \text { (Bireysel farkındalık) }
$$

$\mathrm{Bu}$ değişkenler ile empati arasındaki çoklu korelasyon .41'dir ve bu anlamlı bir değerdir $(\mathrm{F}(2,231)=23.107, \mathrm{p}<.05)$. Diğer bir deyişle, bireysel farkındalık ve seçim hakkı, toplam varyansın \% 17'sinden sorumludur. $\mathrm{Bu}$ bulgu, Sheldon ve Deci'nin (1996) sonuçlarıyla uyumludur (Sheldon ve ark.; 1996). Ancak, Özerk Benlik Yönetimi Ölçeği ve iki alt boyutu ile otonomi puanları arasında (sırasiyla. 06, .07 ve. 02) $\mathrm{p}<.05$ düzeyinde anlamlı ilişki bulunmamaktadır. 
Uyarlaması yapılan ölçeğin her faktörünün güvenirlik derecesi ile maddelerin ayırt ediciliğinin belirlenmesi için Cronbach alfa katsayıları ile düzeltilmiş madde toplam korelasyonları hesaplanmıştır. Hem "seçim hakkı" faktörü için hem de "bireysel farkındalık" faktörü için alfa değeri .70 ve iki yarı güvenirlikleri ise sirasıyla .67 ve .71 olarak bulunmuştur. Daha önce değinildiği gibi, her bir boyuta ait ölçek maddeleri için ayrı ayrı çıkarılan madde toplam korelasyonlarının .20'den yüksek bulunması da ölçeğin alt faktörlerinin güvenirliğini destekler niteliktedir.

\section{TARTIŞMA}

Özerk karar verme, insanların hayatlarına, üstlenecekleri sosyal rollere ve kuracakları kişilerarası ilişkilere dair kararları kendi kişisel tercihlerine dayalı olarak alabilme durumudur (Cook ve Jonikas, 2002). Aslında özerk karar verme, sadece tercih yapmak değildir; aynı zamanda insanların kendi istek ve beklentileriyle tutarlı seçeneklere sahip olmasıyla da ilgilidir. Bireyin istek ya da tercihleriyle tutarlı olmayan pek çok seçeneğin varlığına karşın aynı kişinin değer verdiği hiçbir seçeneğin bulunmaması halinde, kesinlikle özerk karar verme durumundan söz edilemez (Leff ve ark., 2003). Dolayısıyla hangi seçeneklere bireyin değer verdiğinin önemi göz ardı edilmemelidir.

Özerk Benlik Yönetimi Kuramı, daha önce de belirtildiği gibi, içsel ve dışsal güdülenme arasındaki fark ile bunun temel insan gereksinimleriyle ilişkisine odaklanmaktadır. Kuram, insan davranışının ne denli özerk verilmiş kararlara dayalı olduğunu; yani ne ölçüde istemli gerçekleştiğini açıklamaktadır.

Hatırlanacağı gibi, kuram insanların özerk karar verilmiş davranışsal eylemlerini düzenleyerek tutarlı bir benlik duygusunu nasıl geliştirdiklerine de odaklanmaktadır. Hem özerk karar verilmiş hem de kontrol edilmiş davranışlar iradelidir; oysa sadece özerk karar verilmiş davranışlar gerçek bir seçim hissini içermektedir; çünkü bu tercih edilen şey her neyse, onu yapabilmek için kişinin kendini tamamen özgür hissetmesi gerekir (Malthotra, 2004). Dolayısıyla, davranışsal düzenleme ne denli içselleştirilirse, birey bunu o denli kendi özgür tercihinin yansıması olarak algılayacaktır (Deci ve ark., 1994, Malthotra, 2004). İçselleştirme "dışsal kontrol edilmişten" "içten kontrol edilmeye", "özdeşleşmeden" ve "bütünleştirmeye" doğru uzanmaktadır. Bu bağlamda yeterlik, başkalarıyla sosyal ilişki ve özerklik ile desteklendiğinde içselleştirme kolaylaşacaktır (O’Brien, 2006).

Kuşkusuz, bireysel özgürlüğün, sadece kişinin çıkarlarını azamileştirecek kararlar alma becerisi olarak tanımlanması da sakıncalıdır 
(Cook ve Jonikas, 2002). O halde "özerk karar vermenin" makul bir miktarı olması gerekir ve bu özerk karar verme sürekli çizgisi üzerinde "ideal" bir puanı temsil edecektir (Leff ve ark., 2003).

$\mathrm{Bu}$ bilgiler 1şı̆̆ında, insanların çok çeşitli ortamlarda kendilerine sunulan seçenekler arasından ne şekilde tercih yapma eğilimi taşıdıklarını belirlemek anlamlı görünmektedir. Özerk karar verme eğilimini belirlemeye yönelik geliştirilen ve/veya ülkemizde geçerliliği ve güvenirliği sınanmış ölçme aracının bulunmaması nedeniyle, sunulan çalışmanın bu alanda bir boşluğu dolduracağ 1 düşünülmektedir.

Bu çalışma, Özerk Benlik Yönetimi Ölçeği'nin Türkçe'ye uyarlanması ile geçerlik ve güvenirliğini belirlemeyi hedeflemektedir. Özerk Benlik Yönetimi Ölçeği'nin özgün formunda ölçeğin 5'er maddeden oluşan iki alt ölçeği bulunmaktadır. 1, 3, 5, 7 ve 9. maddeler "seçim hakkı" boyutu, 2, 4, 6,8 ve 10. maddeler "bireysel farkındalık" boyutu içerisinde yer almaktadır. Ancak ölçeğin özgün formundaki faktör yapısı ile bu çalışmada elde edilen faktör yapısı ilk analizde aynı çıkmamış; ölçeğin üç faktörlü bir yapıya sahip olduğu görülmüştür. Açıklanan varyans ise \% 41.05 'tir. Fakat birinci faktör \%13.75, ikinci faktör \%21.12 varyans1 açıklarken, üçüncü faktörün \% 6.19'luk bir varyansı açıklaması ölçeğin iki faktörlü kullanılabileceğini düşündürmektedir. Ayrıca analiz sonuçlarına göre, 3. madde, ilk iki faktöre yerleşmemekte, ayrı bir faktörde yer almaktadır. Bu durum, söz konusu maddenin ölçekte yer almayan başka bir yapıyı ölçüyor olabileceğini düşündürmektedir. Bu nedenle 3. madde çıkarılarak ölçek iki faktörlü bir yapıya dönüştürülmüştür. 9 maddelik ölçeğin tekrarlanan doğrulayıcı faktör analizi sonucunda $1,5,7$ ve 9. maddeler "seçim hakk1" boyutuna yerleşirken, 2, 4, 6, 8 ve 10. maddeler "bireysel farkındalık" boyutunda toplanmıştır. Maddelerin özgün formla özdeş bir yapıyı ortaya çıkaracak şekilde dağılmış olması, ölçeğin kültürel olarak benzer özellikleri ölçtüğüne işaret etmektedir.

Ayrıca, dokuz maddelik Özerk Benlik Yönetimi Ölçeği’nin güvenilir olduğu da bulunmuştur. Hem "seçim hakkı", hem de "bireysel farkındalık" faktörleri için Cronbach alfa katsayısı .70 olarak hesaplanmıştır. Her faktöre ait maddeler için hesaplanan düzeltilmiş madde toplam korelasyon katsayıları ile alt ve üst \% 27'lik dilimlerin ortalamalarını kıyaslamak için yapılan $t$ testi sonuçları, faktör maddelerinin iyi derecede ayırt edici nitelikte olduğuna işaret etmektedir. Empatik Eğilim Ölçeği ile Özerk Benlik Yönetimi Ölçeği ve "seçim hakkı" ile "bireysel farkındalık" alt ölçekleri arasında anlamlı bir ilişki bulunmuştur. Ancak Otonomi Ölçeği ile Özerk Benlik Yönetimi Ölçeği ve iki alt ölçeği arasında anlamlı bir ilişki yoktur. Otonomi ile özerk karar verme arasında beklenen ilişkinin ortaya çıkmaması 
araştırma grubu sınırlılıklarına bağlı olabilir. Ancak bir diğer neden otonominin (başkalarından bağımsız karar verebilmenin) kuramda özerklik ile anlamdaş olarak görülmemesi de olabilir. Hatırlanacağı gibi özerk karar verme karar ve eylemlerin sorumluluğunu tek başına taşıyabilme yetisiyle ilgilidir. Dolayısıyla otonomi ve özerk karar verme farklı yapıları temsil etmektedir ve bu bulgu kuramın sayıtlılarıyla tutarlıdır. Gerçekten bireyci kültürlerde daha baskın olan kendi iradesine dayalı karar verme, görece toplulukçu değerleri daha çok benimseyen ülkelerde daha nadir belirginleşiyor olabilir. Dolayısıyla otonom davranışların açıkça vurgulanmadığı koşullarda özerk karar vermenin gizlendiği düşünülebilir. Bilindiği gibi toplulukçu değerler "karşılıklı bağlılık ilişkisini" öngörmekte ve şahsi çıkarlar peşinde koşmak suretiyle davranmayı kınamaktadır. Bu bakımdan Türk kültüründe "otonomi" ve "özerk karar verme" aynı şeylermiş gibi değerlendirilmiyor olabilir. Otonom davranmak Türk kültüründe özerk karar vermeyi güvence altına almamaktadır. Dolayısıyla otonomi ile özerk karar verme arasında bir ilişkinin bulunmaması otonom eğilimlere sahip olmanın, özerk karar verme yönelimine mutlaka yol açmadığına işaret etmektedir. Bu durumda denilebilir ki herhangi bir bireyin içten güdülenmiş özerk kararlar alması onun ne denli otonom olduğunu tahmine izin vermemektedir. Bu durum, bireyin hem özerk karar verebileceğini hem de toplulukçu eğilimlere sahip olabileceğini vurgulayan çalışmalarla (Villacorta, 2006) tutarlıdır. Aynı mantıkla empati başkalarının isteklerine ve beklentilerine duyarlı olmayı sağlar. Davranışlarımızın başkaları için olası sonuçlarını hesaba katmak, kültürel olarak öğrendiğimiz ahlaki bir ilkedir. Dolayısıyla empati ile özerk karar verme birbiriyle ilişkilidir. Başkalarınca sevilme, gözetilme ve onaylanma (başkalarıyla sosyal ilişki) gereksinimi de empatik eğilimlerle bağlantılıdır ve bu diğer kişileri düşünmekle birlikte bireyin, istediği kararı alma eğilimine işaret etmektedir. Dolayısıyla empatik eğilimler, özerk karar vermenin sınırlarını biçimlendirmektedir çünkü başkalarının ne düşündüğüyle ilgilenmek, katılımcı bir ortamı teşvik etmekle herkes için kabul edilebilir kararlar alınmasını destekler (http://im.org/AAIM/Meetings/PastMeetings/ 2006/APDIM/Wksp204-Motivation.pdf).

Sonuç olarak, bu çalışmada elde edilen bulgulara dayanılarak Özerk Benlik Yönetimi Ölçeği'nin ve alt ölçeklerinin Türkçe geçerlik ve güvenirliğinin yeterli düzeyde olduğu düşünülmektedir. Ancak, bu çalışmanın üniversite öğrencilerinden oluşan bir grupla yürütüldüğü göz önüne alındığında, tanımlanmış bir evrenden seçilmiş, daha geniş bir örneklemle doğrulayıcı faktör analizlerinin gerçekleştirilmesinin önemli bilimsel katkılar sağlayacağı önerilebilir. 
Konuyla ilgili literatür incelendiğinde, özerk biçimde kendini yönetebilen bireylerin sahip olduğu bazı özgün kişilik özellikleri, yetenekler ve tutumların var olduğu ve benlik bilgisi, tercih yapabilme becerisi, problem çözme becerisi, içten denetimli olma ve bireysel farkındalık vb. değişkenler aracıllı̆ıyla özerk benlik yönetimi düzeyinin arttırılabileceği önerilmektedir (Welhmeyer ve Schwartz, 1997). Bu öneri, psikometrik özellikleri sınanan Özerk Benlik Yönetimi Ölçeği'nin önemini daha da arttırmaktadır. Çünkü bu ölçek eğitim sürecinde söz konusu bireysel nitelik, beceri, inanç vb. yapıların ne denli biçimlendirilebileceğini belirlemede işe yarayabilir.

Sağlığı koruyucu davranışlara yönelmeyi sağlamak için de özerk karar vermenin arttırılması faydalı olacağından, ölçeğin bu alana yönelik çalışmalarda da kullanılması mümkündür. Örneğin bilindiği gibi, sigara tiryakileri, alkolikler ya da aşırı kilolu kişiler ancak kendileri isteyerek "karar" verdiklerinde, tedavi süreçlerinde başarı söz konusu olabilmektedir.

Temel psikolojik gereksinimlerin karşılandığ 1 çalışma ikliminin, işçilerin içsel güdülenmesini arttıracağ 1 ve dışsal güdülenmenin tamamen içselleştirilmesini destekleyeceği düşünüldüğünde, ölçeğin psikolojik iyilikhali, örgütsel vatandaşlık davranışları, etkin performans gibi önemli örgüt psikolojisi çalışmalarına katkı yapabileceği önerilebilir. Örneğin Baard ve ark. (2004) işçilerin yeterlik, özerklik ve ait olma gereksinimlerinin karşılanma düzeyi ile işteki iyilik hali arasında pozitif ilişkiler bildirmiştir.

Son yıllarda ölçeğin zihinsel sağlıkla ilgili çalışmalarda da (örneğin Leff ve ark., 2003) kullanıldığı hatırlandığında, klinik düzeyde yürütülecek çalışmalara da katkıda bulunabileceği düşünülmektedir.

Tüm bu bilgiler 1şı̆̆ında, Özerk Benlik Yönetimi Ölçeği'nin geçerli ve güvenilir olarak değerlendirilmiş bulunmasının ve iki boyutlu yapısının kültürler arası uygunluğunun belirlenmesinin, bu çalışmanın birincil katkısı olarak değerlendirilmesi mümkündür. Ayrıca bu ölçekle yapılacak araştırmaların, bilimsel alana birçok açıdan katkı sağlayacağı umulmaktadır. 


\section{KAYNAKLAR}

Baard, P.P., Deci, E.L., \& Ryan, R.M. (2004). The relation of instrinsic need satisfaction to performance and well-being in two work settings. Journal of Applied Social Psychology, 34, 2045-2068.

Büyüköztürk, Ş. (2004). Sosyal bilimler için veri analizi el kitabı. Ankara: Pegem Yayıncılık.

Chirkov, V., Ryan, R.M., Kim, Y., \& Kaplan, U. (2003). Differentiating autonomy from individualism and independence: A self-determination theory perspective on internalization of cultural orientations and wellbeing. Journal of Personality and Social Psychology, 84(1), 97-110.

Cook, J.A., \& Jonikas, J.A. (2002). Self-determination among mental health consumers/survivors: Using lessons from the past to guide the future. Journal of Disability Policy Studies, 13(2), 87-95.

Deci, E.D., Eghrari, H., Patrick, B.C., \& Leone, D.R. (1994). Faculitating internalization: The self-determination theory perspective. Journal of Personality, 62(1), 119-142.

Deci, E.L., \& Ryan, R.M. (2000). The "what" and "why" of goal pursuits: Human needs and the self-determination of behavior. Psychological Inquiry, 11(4), 227-268.

Dökmen, Ü. (1988). Empatinin yeni bir modele dayanılarak ölçülmesi ve psikodrama ile geliştirilmesi. Eğitim Bilimleri Fakültesi Dergisi, 21, 155-190.

Gagne, M., \& Deci, E.L. (2005). Self-Determination Theory and work motivation. Journal of Organizational Behavior, 26, 331-362.

Guay, F., Mageau, G.A., \& Vallerand, R.J. (2003). On the hierarchical structure of self- determined motivation: A test of top-down, bottomup, reciprocal and horizontal effects. Personality and Social Psychology Bulletin, 29(8), 992-1004.

Ingledew, D.K., Markland, D., \& Sheppard, K.E. (2004). Personality and self-determination of exercise behaviour. Personality and Individual Differences, 36, 1921-1932.

Iyengar, S.S., \& Lepper, M.R. (1999). Rething the role of choice: A cultural perspective on intrinsic motivation. Journal of Personality and Social Psychology, 76, 349-366.

Jenkins, D.A (2005). Examining the relationships between the satisfaction of basic psychological needs, employee well-being, \& commitment. Unpublished master's thesis, Ottowa Carleton University.

Kowal, J., \& Fortier, M.S. (1999). Motivational determinants of flow: Contributions from self-determination theory. The Journal of Social Psychology, 139(3), 355-368. 
Leff, H.S., Conley, J., \& Campbell-Orde, T. (2003). Getting to systems that promote self-determination through research and evaluation. SelfDetermination \& Psychiatric Disability Conference Papers, Chicago.

Malhotra, Y. (2004). Desperately seeking self-determination: Key to the new enterprise logic of customer relationships. Proceedings of the Americas Conference on Information Systems, New York.

O'Brein, K.E. (2006). Self-determination theory and locus of control as antecedents of voluntary workplace behaviors. Unpublished master's thesis, University of South Florida.

Ryan, R.M. \& Lynch, J. (1989). Emotional autonomy versus detachment: Revisiting the vicissitudes of adolescence and young adulthood. Child Development, 60, 340-356.

Ryan, R.M., \& Dec1, E.L. (2000). Self-determination theory and the facilitation of intrinsic motivation, social development, and well-being. American Psychologist, 55 (1), 68-78.

Şahin, N.H., Ulusoy, M., \& Şahin, N. (1993). Exploring the sociotropyautonomy dimensions in a sample of Turkish psychiatic inpatients. Journal of Clinical Psychology, XLIX(6), 751-763.

Savaşır, I., \& Şahin, N.H. (1997). Bilişsel-davranışçı terapilerde değerlendirme: Sık kullanılan ölçekler. Ankara: Türk Psikologlar Derneği Yayınları.

Sheldon, K.M., Ryan, R., \& Reis, H.T. (1996). What makes for a good day? Competence and autonomy in the day and in the person. Personality and Social Pscychology Bulletin, 22, 1270-1279.

Shogren, K.A. (2006). Exanining the measurement of self-determination and its individual and ecological predictors in students with disabilities. Unpublished doctoral dissertation, University of Kansas.

Tezbaşaran, A. (1997). Likert tipi ölçek geliştirme klavuzu. Ankara: Türk Psikologlar Derneği Yayınları.

Villacorte, M.A. (2006). Contingencies of self-worth: Implications for selfdetermination. Unpublished doctoral dissertation, University of Michigan.

Wehmeyer, M., \& Schwartz, M. (1997). Self -determination and positive adult outcomes: A follow-up study of youth with mental retardation or learning disabilities. Exceptional Children, 63(2), 245-255.

www.psych.rochester.edu /SDT, 25.05.2006.

www.state.sd.us/deca, 24.11.2006.

(http://im.org/AAIM/Meetings/PastMeetings/2006/APDIM/Wksp204-

Motivation.pdf), 12.03.2007.

(http://www.bayar.edu.tr/ saykad/o_aydemir1.pdf), 13.11.2007 